\title{
A Revolta dos Coxinhas: as manifestações de março/2015 em debate.
}

Geraldo Magella Neres, Gustavo Biasoli Alves, Marco Antonio Arantes, Osmir Dombrowski e Vania Sandeleia Vaz da Silva ${ }^{1}$

Resumo: A ala conservadora da classe média brasileira saiu às ruas em um grande protesto organizado nas maiores cidades brasileiras no dia 15 de março de 2015. O texto aqui apresentado reproduz um debate ocorrido nas dependências da Unioeste no Campus de Toledo, organizado pelo Grupo de Pesquisa em Democracia e Desenvolvimento com o objetivo de questionar qual o significado e as consequências políticas imediatas daquela grande manifestação.

Palavras-chave: Brasil; manifestações de março/2015; classe média; democracia.

\begin{abstract}
The conservative wing of the Brazilian middle class took to the streets in large "organized protests" in major Brazilian cities on March 2015. The text presented here is the transcription of the debate occurred in the campus of Toledo of Unioeste, organized by the "Research Group Democracy and Development" in order to question the meaning and the immediate political consequences of that great manifestation.
\end{abstract}

Keywords: Brazil; manifestation of March; middle class; democracy.

\footnotetext{
${ }^{1}$ Docentes do Programa de Pós-Graduação em Ciências Sociais da Unioeste, Campus de Toledo; membros do GPDD, Grupo de Pesquisa Democracia e Desenvolvimento.
} 


\section{Introdução}

O texto a seguir reproduz um debate realizado dia 23 de março de 2015 , no auditório da Universidade Estadual do Oeste do Paraná, campus de Toledo, logo após as grandes manifestações de rua ocorridas no dia 15 do mesmo mês nas principais cidades do país. Optou-se pela publicação da transcrição das intervenções orais em seu formato original, preservando a espontaneidade do evento marcado pelo "calor dos fatos", em detrimento do distanciamento e da frieza que usualmente caracterizam os textos acadêmicos ${ }^{2}$.

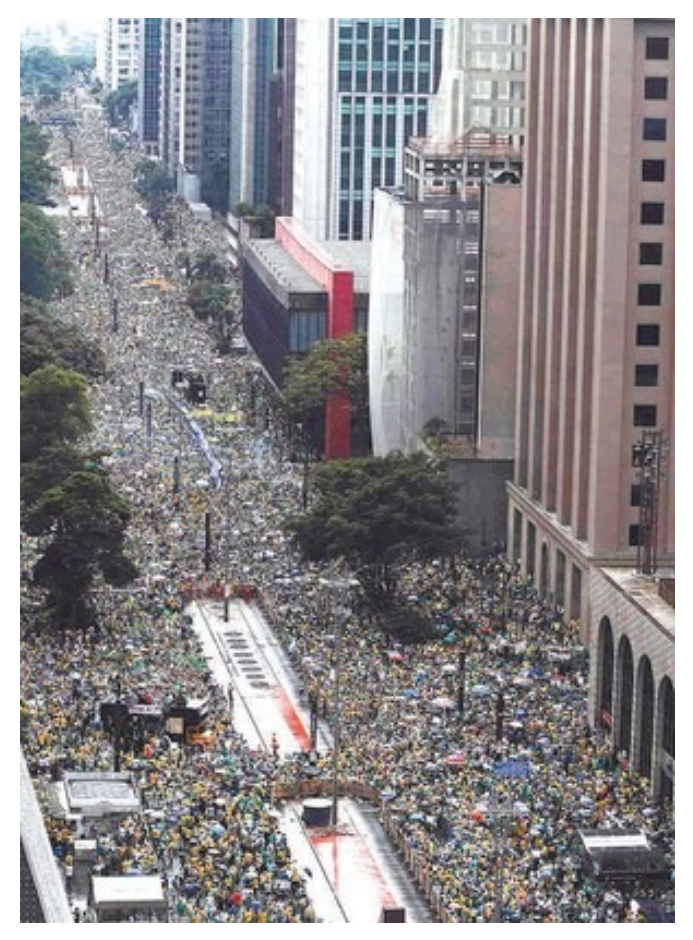

Foto disponível em:

http://ejesa.statig.com.br/bancodeimagens/b3/9b/of/b39bof37c10k39464qoqhqps4.jpg.

Último acesso 22/05/2015.

${ }^{2}$ Agradecemos ao pessoal da Kula Webrádio Universitária que transmitiu o debate e disponibilizou o áudio para transcrição, e ao Thiago Ossucci Santelo responsável pela transcrição. 
Osmir Dombrowski: Neste mês de março de 2015, a classe média brasileira saiu às ruas depois de longo tempo e não foi uma manifestação pequena. Os jornais registraram que nós tivemos a maior manifestação de rua desde a campanha por eleições diretas no início da década de 1980, a "Diretas Já!”. Independente de ser mesmo a maior, ou não; se teve quinhentos mil, ou um milhão de manifestantes em São Paulo, o que deve ser considerado é que a classe média, principalmente, a classe média paulista, foi para as ruas depois de longo, longo tempo. Esse é o fenômeno que eu acho que, do ponto de vista político e sociológico, tem maior relevância para a gente e sobre o qual nós devemos refletir.

Essa classe média, eu vou dizer assim, histórica e sociologicamente, tem as suas origens no Império, depois da Guerra do Paraguai. Mas ela vai se manifestar verdadeiramente como classe política, como classe ativa politicamente, durante a Primeira República no bojo de um movimento que foi chamado de "tenentismo". A primeira manifestação política de peso da classe média foi o tenentismo. E aí nós já temos um elemento que é marcante e que precisa ser considerado. A nossa classe média nasce para a política no bojo de um movimento militar. Um movimento militar e um movimento golpista. Não é uma classe média que entra para a política pelas vias partidárias. Não é um movimento que entra para a política pelas vias institucionais. É um movimento que entra para a política - lógico, historicamente se diz que não existia o canal de expressão institucional que permitisse a expressão daquela classe, então o tenentismo foi a forma histórica possível que ela criou. Mas isto marca significativamente a nossa classe média e a expressão política da nossa classe média através de toda a história do Brasil desde o tenentismo até hoje.

Nós podemos resumir essa história bem rapidamente. Sabe-se que a própria condição sociológica da classe média faz com que ela seja politicamente incerta. As classes políticas determinantes no sistema capitalista são o proletariado e a burguesia; e a classe média não é nem uma nem outra, ela fica no meio das duas, por isso ela é média. No marxismo não existe uma tradição de estudos sobre a classe média, quase sempre ela é tratada como "pequena burguesia". Mas por quê? Porque é um grupo social que não tem uma orientação política própria e tende a seguir a orientação 
político-ideológica da burguesia ou do proletariado. A tendência é ela se definir por um, ou por outro, ou se dividir, que foi o que aconteceu com o tenentismo, nessa primeira manifestação da qual nós estamos falando. Ainda nos anos 1930 o movimento se divide e, com ele, a classe média brasileira. Parte dessa classe média vai ser seduzida pelo Partido Comunista Brasileiro [PCB]; vai se tornar comunista! Nos anos 1930, foi muito chique ser comunista. Uma parte da classe média alta do Rio de Janeiro e de outros grandes centros adorava posar de comunista. Parece estranho isso, mas é verdade; se pegarmos a intelectualidade brasileira naqueles anos, quase que toda ela um dia foi do Partido Comunista, ou seja, militou nas hostes da esquerda como expressão de classe média. Outra parte vai aderir ao fascismo; a outra grande ideologia vigente que disputava as mentes antes da Segunda Guerra Mundial. Bom, para ser bem rápido, pra gente não ficar muito tempo nisso, Getúlio Vargas consegue no golpe de 1937 liquidar, tanto a expressão da vertente de esquerda da classe média, quanto a expressão da vertente de direita. Getúlio impõe uma ditadura de base militar que reprime fortemente o movimento comunista e depois de namorar algum tempo o fascismo de Mussolini, premido pelas circunstâncias da guerra e pela pressão norte-americana se define pelos aliados, e com isso se afasta dos fascistas brasileiros também. Essa ditadura vai ficar no poder até 1945 e em 1950 a gente já tem um cenário um pouco diferente.

Na década de 1950 a classe média de esquerda se reconcilia com Getúlio Vargas em torno das políticas desenvolvimentistas e a classe média de direita fica perdida, pois o fascismo havia sido derrotado na Segunda Guerra Mundial. Essa classe média de direita fica sem projeto político e atravessa os anos 1950 apegada a um discurso moralista entoado pela UDN e personalizado por algumas figuras como Carlos Lacerda e Jânio Quadros. Um discurso moralista contra a corrupção que era complementado pelo discurso contra a ameaça comunista que os governos desenvolvimentistas de Getúlio, Juscelino e depois o de João Goulart representavam. Esses governos, vistos da perspectiva da Guerra Fria que entrava em seu período mais "quente", eram enquadrados como "ameaça comunista".

Mas se existia, de fato, uma ameaça real ao status quo, que ameaça era essa? Em 1950, quando a classe média de esquerda se reconcilia com Getúlio Vargas, se reconcilia com o desenvolvimentismo como teoria política e como orientação ideológica, nós tínhamos um ou dois atores novos no cenário político, um proletariado urbano maior e um campesinato mobilizado politicamente. E esse proletariado 
maior estava organizado em sindicatos que eram oficiais; e o campesinato que entra na cena política através de sindicatos rurais e também com movimentos populares como as Ligas Camponesas, de fato apareciam para a classe média de direita como uma ameaça. E essa ameaça surgia, de certa forma, na esteira das políticas desenvolvimentistas; surgia pelas mãos de Getúlio Vargas, de João Goulart, dos partidos desenvolvimentistas de esquerda, como o Partido Trabalhista Brasileiro (PTB). Então aquela classe média quando fazia o seu discurso contra a corrupção do governo, esse discurso era também pela manutenção da ordem e contra a ameaça comunista, porque entendia que era a corrupção que estava financiando aqueles partidos, que estava organizando aquela massa de trabalhadores. Esse foi o discurso da classe média durante os anos 1950 e início dos 1960.

Em 1964 essa classe média fez, talvez, a última grande manifestação de classe média antes do golpe de abril que foi a Marcha da Família com Deus pela Liberdade. Mas o apelo ao golpe não foi uma coisa que apareceu em 1964. A classe média apelou ao golpe na eleição do Juscelino Kubitschek, quando levaram Getúlio Vargas ao suicídio e com a renúncia de Jânio Quadros em 1961. O apelo ao golpe militar era uma constante. Por que o apelo ao golpe militar era uma constante? Porque aquele segmento da classe média não tinha projeto político; mas via o exército como instituição capaz de garantir a ordem e a manutenção do status quo e que, acima de tudo, era uma instituição com a qual a classe média tinha uma forte ligação histórica.

Então a pauta da classe média, pedindo a intervenção militar já estava colocada desde sempre e em 1964 vem o golpe. O golpe militar significou a saída das ruas da ala à esquerda e também da ala à direita. Mas a politica desenvolvida pelos militares foi uma política voltada para o enriquecimento daquela classe média. Toda a política de desenvolvimento econômico imposta pelos governos militares foi uma política baseada no incentivo à produção de bens de consumo voltados para a classe média, essencialmente automóveis e eletrodomésticos. Nos anos 1960, aquela classe média que tinha o seu carrinho, que tinha televisão, que tinha geladeira, tinha "status". O "must" era você ter o seu carrinho, era você ter a geladeira e ter a televisão. Só que a produção desses bens precisava de operários, então, ainda que seja um modelo voltado para a produção de mercado para a classe média, criou também uma classe operária muito grande. Nós tivemos o inchaço das grandes metrópoles, o inchaço das grandes cidades. Foi formada uma classe popular, uma classe proletária maior ainda. 
Bom, pra ser mais rápido porque eu já extrapolei o meu tempo, a saída dos militares do poder já não foi um movimento onde a classe média teve direção, onde a classe média foi a classe protagonista. Na saída do regime militar, os protagonistas foram os movimentos sociais, de caráter popular, proletários. Quem foi para as ruas para promover a derrubada da ditadura militar foram os movimentos populares e os setores de classe média que tradicionalmente tinham feito a sua opção pela esquerda. Aquela classe média de direita se manteve o tempo inteiro fora. Então o grande protagonista na política brasileira depois da queda dos militares, e aí eu estou falando desde 1978, 1977, são os movimentos populares, os novos, que a sociologia estuda como os novos movimentos sociais, de caráter eminentemente popular, proletário. Os segmentos de classe média quando entram, entram dirigidos, hegemonizados por esses movimentos sociais. Nós não tivemos nenhum grande movimento de classe média em todo esse período.

Bom, com a eleição do governo do PT, do Partido dos Trabalhadores, já no século XXI, a classe média retoma o seu discurso dos anos 1950. Ela começa a ver naquilo que nós, na maioria das vezes, não damos grande valor como as políticas assistenciais, o bolsa família, o FIES, o PROUNI etc., uma ameaça ao seu status quo; uma ameaça à sua condição. Tal qual nos anos 1950 ela via os trabalhadores que estavam chegando e se organizando como ameaça, essa classe média começa a ver nas políticas sociais do PT também uma ameaça. Começa a ter que conviver com preto e pobre nos aeroportos; a ter que ver o seu filho estudar numa universidade particular ao lado de um preto e pobre que tem o FIES. Então são pequenos elementos que começam a aparecer para a classe média como uma ameaça. É uma gente estranha que está entrando no seu território, que começa a ameaçar a sua condição. E essa gente estranha vem financiada, tal qual nos anos 1950, ela vem financiada pela corrupção. É a corrupção que financia um movimento comunista internacional, que começa lá na Venezuela com Hugo Chávez, percorre o Brasil, o Perú, o Uruguai com o Mujica e acaba com os Kirchner na Argentina. É a versão do século XXI do movimento comunista internacional, no imaginário dessa classe média, sustentado pela corrupção. É a corrupção que financia isso tudo. E contra isso, a classe média tem como seu discurso, o mesmo discurso moralista que combate a corrupção e o mesmo ideal, que sempre teve, de retorno às suas origens. Quem eles vão chamar pra resolver esse problema? Os militares. A salvação está aonde? Nos militares. 
Essa classe média só tinha um problema: como ela, praticamente, foi criada na ditadura militar, ela não sabia o caminho das ruas, ela não foi para a rua junto com o proletariado, com os setores populares na queda da ditadura. Ela ficou longe da rua. Aí começava a história do coxinha, né? Eles gostavam de fazer política, até na internet eles entraram bem antes. Aí você entrava na internet e você via as manifestações, mas para as ruas eles não iam, e essa talvez seja a grande provocação que eu vou deixar, eles aprenderam o caminho da rua não foi em quinze de março desse ano, foi em julho de 2013; quando um segmento de classe média ligado ao movimento estudantil foi pras ruas (movimento estudantil no Brasil, sociologicamente, é de classe média, infelizmente, porque as classes populares não entraram na universidade, tá certo?). Então, quando um movimento estudantil de esquerda vai para as ruas em julho de 2013, em um primeiro momento, é visto como sempre foram todas as manifestações populares: são baderneiros, arruaceiros, vândalos, eles depredam... Em um segundo momento, realmente não sei dizer o que aconteceu, mas assistiu-se a Rede Globo de televisão dando a volta, quando se percebeu que aquele movimento não era de apoio ao Partido dos Trabalhadores, mas que era um movimento de classe média que criticava o governo do Partido dos Trabalhadores, eles perceberam que tinham um ponto em comum na crítica ao governo e foram para as ruas juntos.

Observem que naquela hora foram para a rua do jeito que tradicionalmente a classe média de direita vai: sem uma orientação política definida, sem saber direito o porquê. Foram para a rua porque é contra o governo do PT, porque é contra a corrupção, é contra isso, é contra aquilo. Mas - essa é a reflexão que eu queria deixar para vocês - eles aprenderam o caminho das ruas e gostaram. Gostaram e agora em quinze de março foi a primeira vez desde 1964 que vimos a classe média de direita ir para a rua. Isso é um fenômeno político novo para a gente. Nós vamos ter que lidar com isso. Não adianta desqualificar, não adianta fechar os olhos, não adianta ignorar. Nós vamos ter que lidar com o fato de que a classe média, o segmento conservador da classe média brasileira reaprendeu o caminho das ruas e agora vai para os espaços públicos fazer disputa ideológica. E o meu temor é que o ideário político ideológico deles é o de volta a origem, o apelo aos militares é inerente a esse grupo. Ele não consegue elaborar uma proposta política que não seja outra. A proposta política que eles conseguem elaborar é o de retorno às suas origens, é o governo militar. 


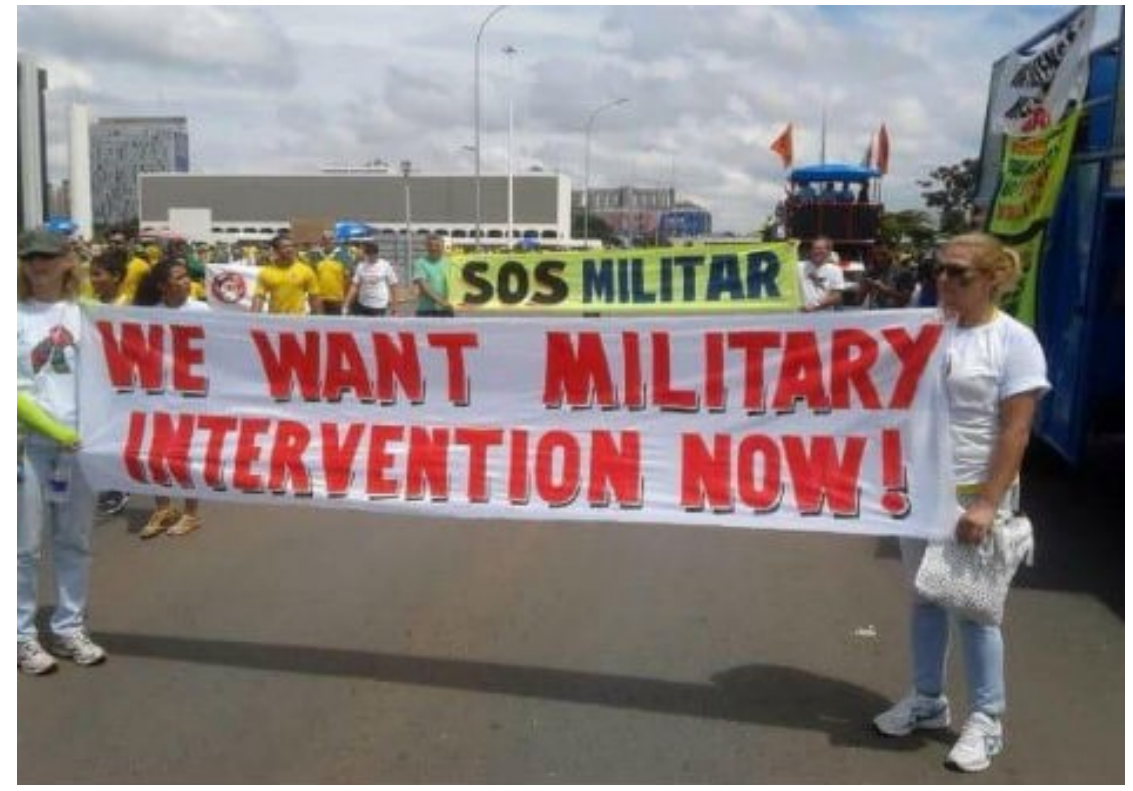

Foto disponível em:

http://imagem.vermelho.org.br/biblioteca/manifestacao_em_brasilia76182.jpg Último acesso 22/05/2015.

Geraldo Magella Neres: Para ajudar a compreender as manifestações ruidosas e antidemocráticas do dia 15 de março de 2015, nas quais milhares de pessoas saíram às ruas de várias capitais e de outras cidades brasileiras, irmanadas pela palavra de ordem generalista de "combate à corrupção", pretendo responder a quatro questões fundamentais. Em primeiro lugar, é preciso identificar quem são os "coxinhas". Quem são estes brasileiros raivosos, vestidos invariavelmente de verde e amarelo, que sacrificaram o descanso do domingo para protestar contra a corrupção? Em seguida, depois de estabelecida a identidade difusa desta fauna curiosa, procurarei identificar a pauta de reivindicações do movimento dos "coxinhas". Afinal de contas, o que querem os "coxinhas"? Depois, contrariando a tentativa da grande mídia, principalmente de seus setores mais engajados (Veja, Globo, Folha de São Paulo e Estadão), de rotular o movimento como sendo essencialmente espontâneo, identificarei os principais organismos envolvidos ativamente na sua fomentação e estruturação organizativa. Ou seja, trata-se de responder à seguinte questão: quem são os articuladores do movimento dos “coxinhas"? Finalmente, poderei abordar a questão central, que é aquela de investigar

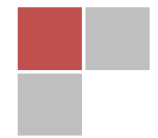


do ponto de vista político e sociológico, o que realmente foi o protesto que se espalhou pelo Brasil no dia 15 de março de 2015.

Quem são os “coxinhas”? Para responder a esta questão vou utilizar duas abordagens complementares. Uma abordagem sociológica, vinculada à identificação da composição social do movimento; e outra abordagem ideológica, que visa explicitar o que os "intelectuais orgânicos" do movimento pensam de si próprios. Esta dupla perspectiva tem a vantagem de equilibrar a definição de quem são os "coxinhas", contrapondo aquilo que dizem de si mesmos com aquilo que de fato são.

Com efeito, da perspectiva sociológica, a grande maioria dos indivíduos que participou das manifestações pertencia à classe média alta. Ou, melhor ainda, pertencia à classe alta baixa, conceito utilizado por alguns autores da sociologia americana que se encaixa perfeitamente à realidade brasileira. Então, do ponto de vista estrutural, a maioria dos manifestantes era composta por profissionais liberais, empresários (pequenos, médios e grandes), militares, comerciantes, ruralistas, socialites, políticos de direita (alguns deles corruptos históricos de longa data), artistas e músicos decadentes, etc. Em suma, sociologicamente, trata-se de um movimento político baseado numa ampla parcela da classe média, mas com fortes ramificações entre algumas frações da classe alta (empresários do setor de serviços, rentistas e grandes barões da mídia impressa e televisiva). É mais do que evidente que entre os protestos, como em todas as manifestações políticas, podemos identificar também indivíduos isolados que não se enquadram neste perfil. Mas a exceção só serve para confirmar a regra.

Mas o que os "coxinhas" pensam de si mesmos? Não quero saber o que os indivíduos isoladamente pensam de si, mas sim qual visão de mundo e qual projeto político seus intelectuais orgânicos difundem de modo ativo através de suas organizações de cultura. A visão de mundo difundida ativamente há quase treze anos (desde a primeira eleição de Lula em 2002) entre esta parcela da população é a de que o PT, o Fórum de São Paulo e o bolivarianismo estão transformando progressivamente o Brasil numa ditadura comunista. Ou, mais precisamente, como seus porta-vozes mais ensandecidos gostam de alardear, numa ditadura gayzista e comunista. Nesta concepção, restaria à classe média alta ou classe alta baixa a tarefa de livrar o Brasil do PT e do comunismo, restabelecendo as condições existentes antes de 2002. Pois só esta parcela da população - que assiste aos telejornais da Rede Globo, que é leitora assídua da Veja, da Folha de São Paulo e do Estadão - teria "massa crítica" 
suficiente para romper com a hegemonia ideológica do "neocomunismo petista". O cimento ideológico mais ativo na manutenção da coesão do bloco é dado pela recusa quase histérica às tímidas políticas sociais de redistribuição de renda e de empoderamento de minorias implantadas pelos diversos governos do PT.

O que querem, afinal, os "coxinhas"? Como decorrência direta da despolitização e da inexperiência organizativa da classe média, não existe ainda uma agenda política coletiva propositiva por parte do movimento, mas apenas um anseio difuso da necessidade de salvaguarda do status quo. Este posicionamento político encontra a expressão mais objetiva na palavra de ordem moralista do combate à corrupção e de extinção do PT. Este é o leitmotiv que tem unido os diferentes partidos ${ }^{3}$ que constituem o conjunto do movimento. Contudo, de modo fragmentário, as diversas seções ou frações dos "coxinhas" parecem querer coisas diferentes, o que evidencia as gradações ideológicas do movimento. Alguns, aparentemente os mais "racionais" entre a turba de elite, pressionam pelo retorno das políticas neoliberais da época do FHC. A Presidente Dilma parece ter compreendido bem esta reivindicação, sinalizando com a possibilidade de atender a esta fatia do movimento. Outros, principalmente os grupos ligados aos militares, às organizações religiosas ultraconservadoras (Opus Dei, TFP, etc.) e ao pentecostalismo evangélico fundamentalista (temperado com doses cavalares de "teologia da prosperidade", como é o caso do Pastor Silas Malafaia e congêneres), mesmo que nem todos professem abertamente, querem a extinção do PT, a intervenção militar e o retorno da ditadura. Outros ainda, uma parcela considerável do movimento, querem o impeachment da Presidente Dilma e a condução do candidato derrotado do PSDB à presidência da república. O que demonstra o grau de analfabetismo político e de desinformação da classe média brasileira, provando que a posse de um diploma universitário não supera os estragos produzidos por uma imprensa partidária e manipuladora.

Quem são os articuladores do movimento dos “coxinhas”? Ou seja, quais são as organizações ou institutos que fornecem uma direção consciente ao movimento? Aqui é preciso fazer uma distinção básica entre os difusores da ideologia dos "coxinhas" e os organizadores logísticos do movimento. Os difusores da ideologia dos “coxinhas" são os intelectuais comprometidos com a sistematização de uma

\footnotetext{
${ }^{3} \mathrm{O}$ termo partido é empregado aqui num sentido bastante ampliado, compreendendo o partido político tradicional, mas também os jornais, as revistas, os programas televisivos, os institutos, etc. Enfim, por partido entendemos toda forma de organização cultural que veicula ativamente uma determinada visão de mundo no interior da sociedade civil.
} 
visão de mundo direitista e ultraliberal reunidos em torno de organizações como revista Veja, Época, Isto é; jornais como a Folha de São Paulo, o Estado de São Paulo; os telejornais da Rede Globo, principalmente na sua grade de programação do canal pago Globo News; os Instituto Millenium, Von Mises, etc. Este intelectuais orgânicos da nova direita brasileira, cujo patrono máximo é a figura singular de Olavo de Carvalho, parecem querer copiar o que faziam os intelectuais militantes de esquerda até meados dos anos oitenta. Eles trabalham ininterruptamente, utilizando todos os meios e veículos de difusão disponíveis, para sedimentar uma nova visão de mundo negadora do "neocomunismo petista"4. Com o apoio irrestrito da grande mídia, começaram, a partir de 2002, a difundir esta visão de mundo reacionária que desaguou nas manifestações do dia 15 de março de 2015. Mas esta corrente difusa de opinião construída nas franjas da classe média alta brasileira não teria se mobilizado sem a atuação dos organizadores logísticos do movimento. E aqui o apoio organizacional do MBL (Movimento Brasil Livre), do Movimento Vem pra Rua, do Revoltados On-Line, de alguns quadros dirigentes e do aparato burocrático do PSDB foi essencial para o sucesso das mobilizações do dia 15 .

Finalmente posso abordar a questão central que propus. O que foi o protesto do dia 15 de março de 2015? Para início de conversa, adianto que há uma diferença essencial entre os protestos dos "coxinhas" e os protestos populares brasileiros recentes, como por exemplo, o movimento "Diretas Já" (1984) e o "Caras Pintadas" (1992). Entretanto, e isto não é casual, existem elementos de ligação entre as "Jornadas de Junho" (2013) e a "revolta dos coxinhas" (2015). Os mais importantes residem na composição estrutural de classe dos dois movimentos, ambos majoritariamente constituídos pela classe média e na fragmentação da pauta de reivindicações. Principalmente se considerarmos os últimos protestos de 2013, já visivelmente hegemonizados pela direita (quando se proibiu a presença de bandeiras vermelhas). As últimas jornadas de 2013 foram o ensaio geral para a "revolta dos coxinhas" de 2015.

Por outro lado, a "revolta dos coxinhas" também foi catalisada pelo clima político pós-eleitoral. A "revolta dos coxinhas" de 15 de março de 2015 é o resultado de uma polarização social que começou a se expressar já nas últimas "jornadas" de 2013, que se acentua nos protestos contra a

\footnotetext{
${ }^{4}$ Eles acreditam piamente nas ideias estapafúrdias do Olavo de Carvalho de que o PT é comunista e de que o Brasil está se transformando numa ditadura bolivariana.
} 
Presidente Dilma durante a abertura da Copa do Mundo em São Paulo (2014) e que atinge o seu ápice no mês de março de 2015, em virtude da derrota apertada de Aécio Neves na eleição presidencial. Agora, já devidamente “depurados”, em função da difusão de sua ideologia reacionária para amplos círculos da classe média, os "coxinhas" puderam mostrar a sua cara agressiva abertamente. E lá estavam eles: idosos, casais com crianças (acompanhados de suas babás, evidentemente), jovens da "nova direita", artistas decadentes, militares da reserva, pastores evangélicos de moral suspeita, corruptos históricos do DEM e do PSDB, peruas de plantão, etc., todos pedindo o fim da corrupção. O que demonstra que o protesto do dia 15/03/2015 foi, na sua fachada externa, um movimento contra a corrupção (entenda-se a corrupção do PT); mas na sua essência, tratou da primeira manifestação explícita de um movimento político de direita constituído pela classe média para lutar contra as políticas de transferência de renda introduzidas pelo PT e pela manutenção do status quo.

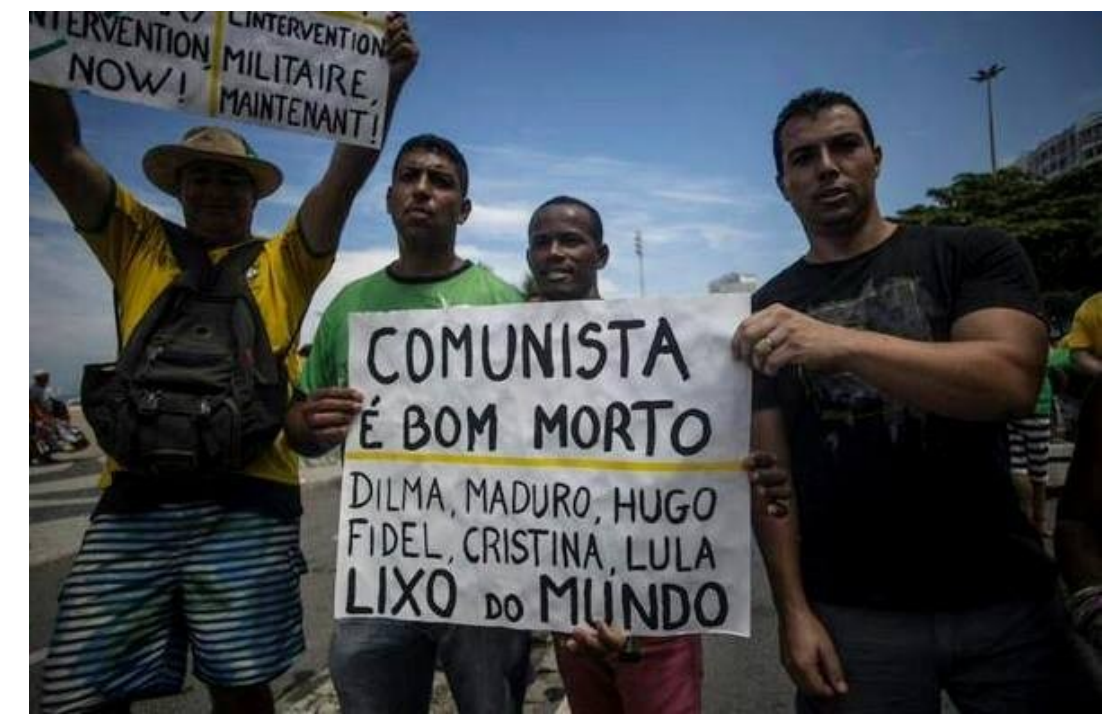

Foto disponível em

http://www.pragmatismopolitico.com.br/wp-content/uploads/2015/03/fora-dilma8.jpg. Último acesso em 22/15/2015.

Vânia Sandeleia Vaz da Silva: Depois que o Osmir retomou quais foram os outros momentos historicamente importantes dos "coxinhas"; e o Geraldo fez um "diagnóstico" bem detalhado dessa 
"doença"; vou tentar oferecer uma "receita", considerando que os estudantes do primeiro ano do curso de Ciências Sociais estão acompanhando o debate, e, minha preocupação quando acompanho esses “movimentos" é que existem muitas pessoas que "participam” sem entender o que está em jogo. Quer dizer, trata-se de um movimento encabeçado por "coxinhas"; organizado por "coxinhas"; mas que tem atraído pessoas "inocentes" que se revoltaram politicamente com alguns "problemas" que identificam na situação atual e foram para as ruas também, mas sem entender quem são os "coxinhas" e o que é que estão de fato defendendo e criticando. Quando ouvi algumas pessoas - daqui do curso - dizendo que tiveram que se "justificar" no Facebook porque não tinham participado da manifestação, eu comentei: "você teria que se justificar se fosse", pois, obviamente, nossos acadêmicos não são "coxinhas"...

Qual a receita? Para quem não quer se tornar coxinha ou para aqueles que eventualmente convivem com alguém que poderia se tornar coxinha, mas que não pertence à "classe" que fornece os principais elementos para a "revolta dos coxinhas"? Entendendo que os coxinhas ricos tem razões reais e suficientes para aderir ao movimento dos "coxinhas", pois estão defendendo sua ideologia e situação material, ou seja, se existe algum pobre acompanhando ou aderindo de modo acrítico aos "coxinhas", então temos um papel, nós, cientistas sociais, maioria da audiência aqui, devemos nos preocupar... Para quem pretende salvar os desavisados de transformarem-se em coxinhas, vou sugerir três poemas que são essenciais para quem não quer se tornar coxinha e não quer ver os seus amigos se tornarem “coxinhas”. O primeiro poema é "O Analfabeto Político" de Bertold Brecht:

\section{O Analfabeto Político}

O pior analfabeto

É o analfabeto político,

Ele não ouve, não fala, nem participa dos acontecimentos políticos.

Ele não sabe que o custo de vida, o preço do feijão, do peixe, da farinha, do aluguel, do sapato e do remédio dependem das decisões políticas. $O$ analfabeto politico é tão burro que se orgulha e estufa o peito dizendo que odeia a política. 
Não sabe o imbecil que, da sua ignorância politica nasce a prostituta, o menor abandonado, e o pior de todos os bandidos, que é o político vigarista, pilantra, corrupto e o lacaio das empresas nacionais e multinacionais.

Superar a "ignorância política" é um movimento fundamental, mas é possível deixar de ser analfabeto político e continuar um pseudo-coxinha porque se a pessoa não liga a causa certa ao efeito que está querendo combater, poderá ir para a rua e ficar ao lado daquelas figuras que o Geraldo enumerou. Depois de deixar de ser analfabeto político é preciso avançar.

O segundo poema é o “Operário em construção”, do Vinícius de Moraes, e a sua importância está em explicar, com muita beleza, como se dá o processo de consciência, ou seja, como é que uma pessoa consegue sair da situação de alienação - de trabalho alienado, de vida alienada - e começa a perceber que são os trabalhadores e trabalhadoras que produzem e constroem tudo, inclusive as nossas relações, a nossa vida, o nosso mundo. É possível que nesse processo cada um comece a perceber qual a verdadeira causa dos problemas que estão incomodando as pessoas que, sem se enquadrarem na condição de "coxinhas", sentiram um início de sentimento de "revolta" que é importante, mas ainda não está direcionado corretamente. O poema é muito extenso - por isso não vou incluir ele inteiro aqui - mas existem alguns trechos que merecem uma atenção especial. Nos primeiros versos, Vinícius de Moraes apresenta o operário em estado completamente alienado, alguém que realiza seu trabalho diariamente - para que possa receber um salário e sobreviver - mas que não tem consciência de seu papel no mundo:

\author{
O operário em construção \\ [...] \\ Era ele que erguia casas \\ Onde antes só havia chão. \\ Como um pássaro sem asas \\ Ele subia com as casas \\ Que the brotavam da mão. \\ Mas tudo desconhecia \\ De sua grande missão:
}


Não sabia, por exemplo

Que a casa de um homem é um templo

Um templo sem religião

Como tampouco sabia

Que a casa que ele fazia

Sendo a sua liberdade

Era a sua escravidão.

[...]

Mas ele desconhecia

Esse fato extraordinário:

Que o operário faz a coisa

E a coisa faz o operário.

Depois dessa compreensão inicial, o operário começa a ficar "revoltado", começa a dizer "não" e a notar a desigualdade entre ele - quem realmente "constrói" o mundo pelo trabalho - e o patrão que o expropria. E além de compreender, passa a se organizar e "conversar" com outros operários a respeito de sua "descoberta". Claro, daí enfrenta a "delação"; a tentativa de "cooptação" - quando o patrão lhe oferece "vantagens" - mas continua firme em sua decisão, porque percebeu, mesmo, qual era a real "causa" de sua revolta:

[...]

E aprendeu a notar coisas

A que não dava atenção:

Notou que sua marmita

Era o prato do patrão

Que sua cerveja preta

Era o uísque do patrão

Que seu macacão de zuarte

Era o terno do patrão

Que o casebre onde morava

Era a mansão do patrão

Que seus dois pés andarilhos

Eram as rodas do patrão

Que a dureza do seu dia

Era a noite do patrão

Que sua imensa fadiga

Era amiga do patrão.

E o operário disse: Não! 
E o operário fez-se forte

Na sua resolução.

[...]

O operário via as casas

E dentro das estruturas

Via coisas, objetos

Produtos, manufaturas.

Via tudo o que fazia

O lucro do seu patrão

E em cada coisa que via

Misteriosamente havia

A marca de sua mão.

E o operário disse: Não!

- Loucura! - gritou o patrão

Não vês o que te dou eu?

- Mentira! - disse o operário

Não podes dar-me o que é meu.

[...]

E o operário ouviu a voz

De todos os seus irmãos

Os seus irmãos que morreram

Por outros que viverão.

Uma esperança sincera

Cresceu no seu coração

E dentro da tarde mansa

Agigantou-se a razão

De um homem pobre e esquecido

Razão porém que fizera

Em operário construído

O operário em construção.

Retomando, a receita inicial com uma análise do poema do Brecht, "O Analfabeto Político"; depois a compreensão do processo de consciência a partir do poema de Vinícius de Moraes, "Operário em Construção" - não basta ler, é preciso estudar para entender quem é que, na verdade, constrói o mundo e todas as coisas que precisamos para sobreviver, quem é que trabalha de fato e quem é que deveria de fato exercer o poder, ou seja, definir os rumos da vida em comum. Depois, o próximo poema explica a origem das riquezas - inclusive a dos “coxinhas". Trata-se do poema "As Riquezas Injustas" de Ernesto Cardenal: 


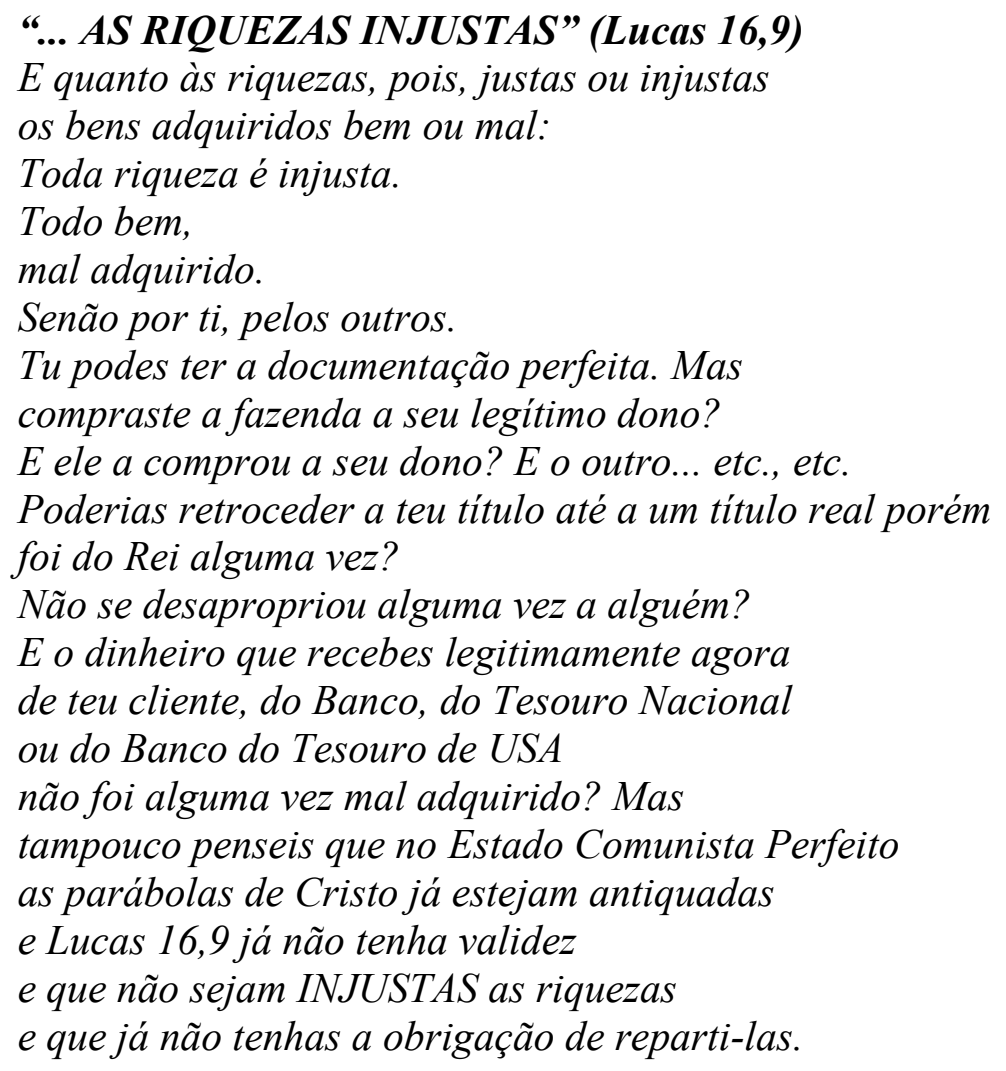

Qualquer pessoa que alcançou a compreensão deste poema não é "coxinha", nunca vai ser e dificilmente vai conseguir conversar com os "coxinhas", sejam pobres ou ricos. Não tem como esquecer depois que compreendemos algo "pela causa", e, é basicamente isso que esse poema permite: toda riqueza é injusta, basta rastrear sua origem. Assim, num primeiro momento deixar de ser analfabeto político; segundo momento, entender quem é que realmente constrói o mundo, o operário em construção; terceiro momento, rastrear o fato básico de que todas as riquezas são injustas.

Como comprovar esta tese? Uma opção é participar do nosso grupo de pesquisa, que, atualmente está envolvido numa pesquisa coletiva que visa desenvolver um conceito de democracia socialista - e, para tanto, irá percorrer as principais "experiências" de democracia, desde a Grécia, passando pelas tentativas históricas mais interessantes a respeito, explorando a teoria política que estas experiências geraram. A principal autora e que será nosso ponto de partida é a pensadora marxista Ellen Meiksins Wood, iniciando por seu livro "Democracia contra Capitalismo". Qual é o argumento 
principal da autora? Ela explica por que o capitalismo é incompatível com a democracia. O que é democracia? Bem, se for concebida etimologicamente, como tem que ser, quando pensamos em uma democracia substantiva, trata-se do governo do povo ou pelo poder do povo. E o que é o capitalismo? É o governo de classe pelo capital. A democracia é incompatível com o capitalismo porque para que seja substantiva exigiria a destransformação em mercadoria de todos os aspectos da vida que tem importância - pois tudo o que foi transformado em mercadoria, pelo capitalismo, deixou de estar ao alcance da responsabilização democrática. Mas criticar a democracia formal exige que se faça uma ressalva importante.

Pensando na nossa realidade - no Brasil contemporâneo - depois que o Partido dos Trabalhadores (PT) venceu as eleições presidenciais, principalmente, a esquerda - e aqueles que se localizam mais à esquerda no espectro político; e bem mais à esquerda da esquerda - nos habituamos a criticar a "democracia" como sendo apenas um procedimento formal, como não tendo importância e acho que cometemos um grande erro fazendo isso. Porque no fim das contas, tudo o que se conquistou de liberdade civil, política e de participação democrática foi uma "conquista" e que envolveu, sempre, muita luta. Quando começamos a fazer a crítica, nos esquecemos do quanto as conquistas democráticas são importantes e do quanto para o capitalismo é aceitável essa cidadania limitada, mas é melhor do que não ter cidadania nenhuma. Esquecemos esse detalhe.

A partir da nossa pesquisa vamos retomar o conceito de democracia substantiva e também recuperar o conceito de liberdade para recontar sua história - que é uma história que nós construímos, os socialistas, os libertários, não os liberais. Ninguém ganhou mesmo essa liberdade "limitada" de presente. Por que estou receitando os três poemas? Porque nós precisamos contribuir com o processo de consciência das pessoas que estão indo para essas manifestações - de "coxinhas" - por que estão num primeiro estágio ou momento de revolta, mas ainda estão alienadas - aliás, é essencial voltar a discutir os conceitos de alienação e ideologia - porque alguém vai dar "conteúdo" para essa revolva e se a esquerda não fizer, a direita vai fazer, como está fazendo.

Então eu sugiro a todos - além dos professores, também os acadêmicos e acadêmicas - que deixemos de desqualificar essa democracia - brasileira - que é limitada, mas que pode ser tirada de nós, não podemos esquecer o quanto se trata de uma experiência recente. Sugiro também, para todo 
mundo que está indignado que venha fazer a pesquisa conosco. Não é só uma atividade intelectual, é aquilo que nós podemos fazer sendo cientistas sociais, é assim que nós transformamos nossa prática em uma ação política também.

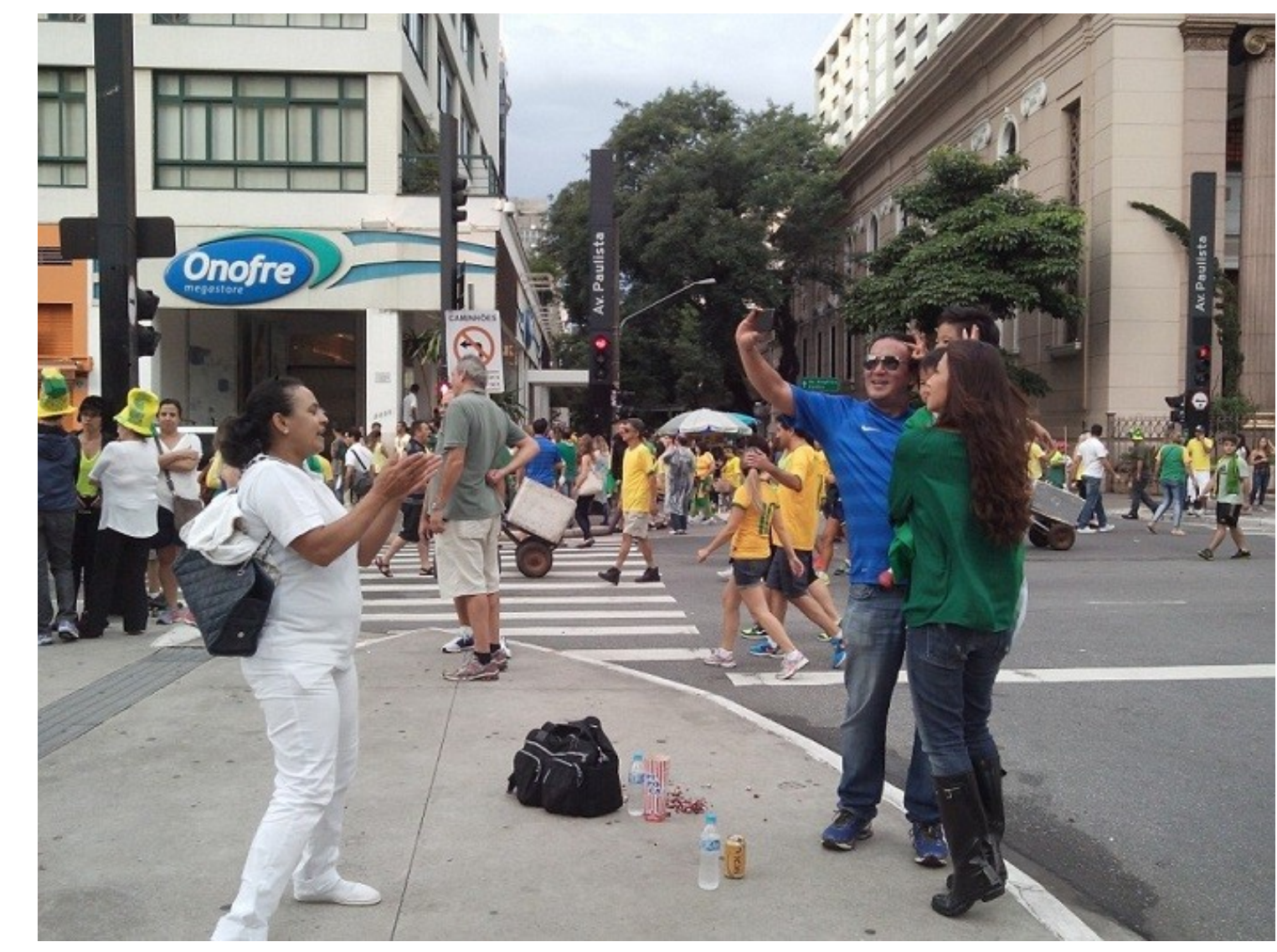

Foto disponível em http://www.pragmatismopolitico.com.br/wp-content/uploads/2015/03/baba.jpg. Último acesso em 21/05/2015.

Gustavo Biasoli Alves: Fiquei muito contente com a ideia do grupo de organizar este evento, no começo eu fiquei um pouco preocupado com o título sugerido: "A Revolta dos Coxinhas", que me pareceu alguma coisa pouco séria, mas percebi que o debate aqui é bastante aprofundado e quero dar algumas contribuições. 
Primeiro identificar que não foram só os coxinhas que saíram às ruas, mas havia três movimentos mais ou menos coincidentes. Os primeiros a sair foram as pessoas pró-governo, no dia treze $^{5}$. Emblematicamente é o número do partido da presidente Dilma, no dia quinze você tem a saída dos coxinhas e em conjunto com isso você tem algumas entidades sérias como a OAB, a CNBB propondo reforma política. Então, o que está acontecendo é alguma coisa que vai um pouco além da "Revolta dos Coxinhas", mas independente disso o movimento é expressivo porque ele tem uma capacidade de pressão, embora difusa por causa da sua agenda pouco clara. É interessante explorar um pouco os impactos disso para o sistema político.

Bom, quem saiu dia treze, saiu em defesa do governo e saiu propondo a manutenção do projeto político que está instaurado. No dia quinze você tem a expressão de uma revolta difusa, confusa e às vezes até mal instrumentalizada. O que eu entendo é que de alguma maneira isso está colocando alguns questionamentos importantes para o sistema político. $\mathrm{O}$ primeiro fato para a gente destacar aqui é que por mais que a agenda dos coxinhas seja como é, o fato da população sair às ruas com dois projetos políticos conflitantes em datas próximas e você ver manifestações pacíficas isso é um ponto que marca: temos uma democracia razoavelmente saudável. Outro ponto que marca a saúde dessa democracia é que, de alguma maneira, essa pressão das ruas está fazendo com que as instituições políticas se mexam. Está fazendo com que o governo se mexa e está fazendo com que o Congresso Nacional, que os partidos, um pouco com que o judiciário também se mexa. O maior problema aí é o fato que você tem um grupo grande de pessoas que não tem muito claro para onde vai e nem quem segue, e várias delas às vezes apelam para regimes autoritários ${ }^{6}$.

Outro ponto que essas manifestações apontam é que quando você vê partidos do governo, partidos da base governista batendo cabeça, não sabendo como responder ao que foi colocado, você vê o Congresso Nacional indo para um lado, o governo indo para outro... É o quê? Um desgaste da fórmula política hoje existente, que é o presidencialismo de coalizão. Esta formula parece ter atingido certo limite, ou ao menos a maneira como ela vem sendo trabalhada nos últimos dez, doze anos atingiu

\footnotetext{
${ }^{5}$ Em 13/03/2015 ocorreram manifestações de rua pró governo Dilma Rousseff.

${ }^{6}$ Ainda que o número de manifestantes que assim o fazem seja pequeno e que os militares tenham dito reiteradas vezes que não sairão da caserna, a idealização do passado militar como período de ordem, pouca corrupção e punição apenas aos que não seguiam a lei é temerária.
} 
um limite. Qual é este limite? Você montar uma coalizão com partidos muito grandes, com partidos muito dispares ideologicamente é uma coisa complicada.

Foi fácil de governar? Foi. Durante os dois primeiros mandatos do PT foi porque como havia uma liderança carismática que de alguma maneira conseguia catalisar tudo isso e dar uma direção para isso tudo. $\mathrm{Na}$ ausência dessa liderança isso fica muito mais complicado. E a partir daí se tem o quê? Os partidos da base não se entendem, o Congresso se rebela e passa a exercer certo poder de veto, ainda que a qualidade das lideranças congressistas que estão exercendo esse poder de veto seja altamente questionável.

É ruim tudo isso que está acontecendo? No meu modo de entender não é não. Por quê? Se não tivéssemos as coalisões montadas para que o Partido dos Trabalhadores chegasse ao poder, talvez a gente tivesse ficado muito naquele reme-reme, naquela coisa meio insossa, sem graça, de escolher o presidente do PSDB, o presidente do PMDB (talvez ou de outro partido mais ao centro ou à direita como o DEM ou outra derivação do PFL), ou ainda entre uma política neoliberal mais a direita ou uma política meio fisiológica, enfim, nessa coisa meio massa de coxinha mesmo e talvez não tivéssemos uma presidente, uma mulher como presidente da república por duas vezes consecutivas e ainda num partido de centro-esquerda e que alguns até dizem de esquerda. Então, o que acontece, nós já temos uma democracia consolidada do ponto de vista formal? Sim. Em alguns pontos a mais, nesse ponto de vista.

O que está faltando para nós, nesse momento, e que pode ser uma agenda propositiva em se pensando a "Revolta de Coxinhas"? Esgotamento de presidencialismo de coalisão e tudo mais? OK! Mas o que propor a partir daí? Os nossos mecanismos de controle político são muito frágeis, eles são muito débeis e extremamente questionáveis. Por quê? Porque eles ainda se resumem a opinião pública razoavelmente informada e participativa, eleição, controle parlamentar, mínima democracia participativa e alguma publicidade, e eu faço aqui uma distinção entre publicidade e propaganda do governo, né? Quer dizer, não é publicidade no sentido de dar seus atos a conhecer, é uma construção em cima desses dados e há muito pouca explicação em cima desses atos. Isso tudo numa comunidade de eleitores mal instruídos e educados o tempo todo a não gostar de política. 
Não são só os coxinhas à direita que não gostam! Há setores da direita que são democráticos e outros não, assim como uma parte da esquerda é democrática e é politizada, e outra não, mas de uma maneira geral, os nossos eleitores não gostam de política, a nossa população não discute política a não ser quando ela é instigada de alguma forma. Um pouco numa eleição presidencial ou por algum escândalo de corrupção ou alguma coisa assim, o que nos reitera a necessidade e o desafio de tornar a política algo cotidiano, palatável e corriqueiro para a maioria da população.

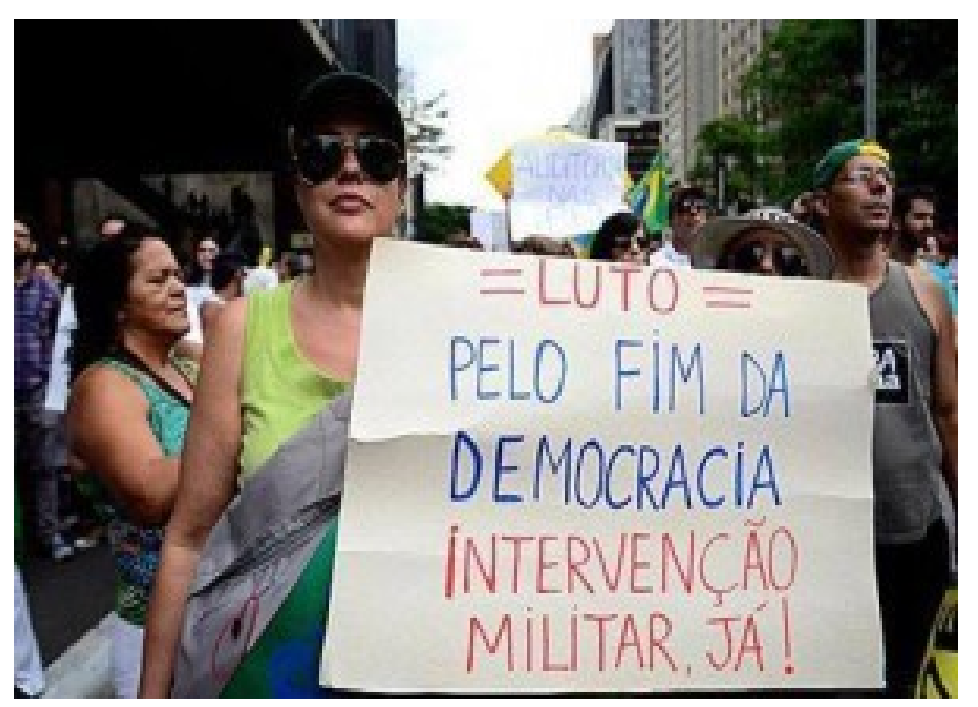

Foto disponível em: http://farofafa.cartacapital.com.br/wpcontent/uploads/2015/03/10469041_327504944117863_1453900548489674244_n-300x193.jpg. Úlitimo acesso em $21 / 05 / 2015$.

Marco Antonio Arantes ${ }^{7}$ : Ao iniciar essa reflexão sobre o dia 15 de março logo me veio à cabeça a crônica "Coma e Emagreça", de Stanislaw Ponte Preta, e que compõe as crônicas satíricas e humorísticas de "Primo Altamirando e Elas" (1962). A curtíssima crônica é finalizada com um diálogo entre um bêbado e um vendedor de empadas.

\footnotetext{
${ }^{7}$ Instigado pelo debate, nosso colega Marco Antonio encaminhou-nos o texto aqui reproduzido.
} 
“- Eu quero aquela ali - apontou

- Qual? - perguntou o homem

Aquela ali, que só tem uma mosca pousada nela

Donde se conclui que quem escolhe a empada nossa de cada dia...é a mosca"

Não sei exatamente o motivo que me fez lembrar da crônica de Stanislaw, cujo nome verdadeiro era Sérgio Porto, jornalista, escritor e crítico ferrenho do golpe militar de 1964. O texto não se referia diretamente às coxinhas, mas as empadas, e não está relacionado ao "Garoto Linha Dura", o mais emblemático personagem de Stanislaw naqueles sombrios tempos políticos. A obra é anterior ao golpe. O que ficou mesmo foi à ideia da mosca. Algo está bichado, estragado e cheirando mal. Parece-me que aqui houve uma inversão de valores. Não foi a mosca que escolheu a coxinha, mas a coxinha que escolheu a mosca.

Em sua crônica "Manifestações Políticas", de 1921, Lima Barreto esmiuçou satiricamente às manifestações políticas num dialogo entre um general e um político:

"A propósito de recentes e ruidosas manifestações políticas, contou-me um plácido e filosofo o seguinte: (...)

- Quem é essa gente que me aclama assim?

- É a mesma que o vaiou, não há muitos anos, Excelência.

- Como mudou!

- É porque ela mudou de vestuário. Há nisso uma questão de moda e de sucesso. Excelência.

"Nisso um bêbado ou um maluco antepassado certamente de Quincas Borba, gritou bem alto:

- Ao vencedor, batatas!

O meu amigo, rematou assim o apólogo:

- Esta ai a filosofia das manifestações políticas, toda ela.

Para todo salgado há uma receita, mas não acredito que toda receita seja pública. Na maioria dos casos a receita não sai do papel. Para a preservação de privilégios e vigência de uma ordem social, talvez o segredo seja a melhor estratégia de alguns grupos sociais. Esconder-se por trás de palavras de ordem vazias e faixas com textos ocos que clamam a volta dos militares é uma estratégia cada vez mais pública. Há um ar tragicômico nessas manifestações. Onde se banha de merda há muito perfume para não tapar às narinas. Um grupelho de privilegiados agora quer falar em nome da humanidade e de uma 
política sem interesses escusos. Nada mais surreal do que o deputado convocando seus eleitores às urnas, que muito lembra coxinhas que se sentem ameaçados. "Desde que minha mulher e os meus filhos passem melhor de cama, mesa e roupas, a humanidade ganha".

Falar em nome da pátria, da bandeira e da política justa, apartidária e anticorrupta soa mais como uma estratégia de marketing político. Lima Barreto dizia na crônica "O Patriotismo" (1914) que " $a$ pátria é uma ideia religiosa e de religião que morreu, desde muito.".

De revolução aqui não há nada, mas um conservantismo, um reacionarismo com cara de reformismo de arranjo de poderes. É por isso que Deleuze em "Intelectuais e Poder" (1972) afirmava que o reformismo era antes de tudo uma noção boba e hipócrita: "Ou bem a reforma é elaborada por pessoas que se pretendem representativas e que professam falar pelos outros, em nome dos outros, $e$ isso é um arranjo do poder, uma distribuição de poder que se duplica por uma repressão aumentada; ou bem é uma reforma reclamada, exigida por aqueles a quem ela concerne, e ela cessa de ser uma reforma."

Tratar a política e os políticos como seres completamente neutros seria no mínimo uma pretensão absurda. Que tal uma escola técnica de Deputados aberta para todos brasileiros? Em sua crônica "Escola De Deputados" (1915), Barreto sugere que o curso seja "meramente prático. Nada de coisas indigestas. Não há cadeiras de economia política, de finanças, de sociologia, de história social ou política, de geografia política; nada disso: o curso é prático, simplesmente prático e dura o pequeno espaço de dois anos. O primeira ano compõe-se das seguintes cadeiras: francês das pensões chics e respectivos exercícios práticos; falsificações de atas e assinaturas de eleitores; meios e modos de fazer os defuntos votarem; o sistema de vestir economicamente na Barra do Rio ou no Brandão. Para a primeira cadeira, há muitos candidatos, entre os quais velhos e aposentados deputados".

Seriam os coxinhas atemporais? Torço para que sejam temporais, com prazo de validade como acontece com qualquer coxinha fresca. Só que não há nada de inocente e patriótico na manifestação de 15 de março.

Desde que foi recortado pelos portugueses no século XVI, o Brasil deixou claro que o extermínio era a palavra de ordem. Índios e sequestro de mulheres e homens africanos que se tornaram escravos 
era rotina nos trópicos. Era um grande negócio. E essa escravidão foi ao limite. Não houve pais no mundo que levou tão a sério a escravidão como o Brasil. O negro foi sugado como carvão até o último segundo à base de torturas e repressão. A fantasiosa "democracia racial” da Casa Grande não conseguiu esconder o terror por debaixo do tapete. A sujeira estava escancarada.

E a perseguição perdurou, republicamente, na era Vargas. O Estado Novo não era tão novo assim. O espetáculo de extermínio, expurgo e sequestro continuou a todo vapor. Ficar de boca calada era um conselho de Estado.

Então se populariza a ideia que no Brasil é antes de tudo democrático e sua democracia foi fruto de incansáveis "diálogos". Tudo pode ser negociado. Vivemos agora numa democracia!! Nessa democracia coube muita coisa: extermínios de crianças na Candelária, repressão em FEBEMs e CASAs, tráfico de crianças, formações de quadrilhas, conflitos de terras com repressão policial e mortes, Carajás, balas perdidas nas grandes metrópoles, escolas e universidades públicas sucateadas, favelas gigantescas e Carandirus e presídios com mega lotação de detentos. Nunca na história a democracia foi tão teatralizada.

Desde a criação do Hino Nacional em 1889 como símbolo oficial da República a Panaceia Geral ocupou seus espaços. A defesa do AI-5 com a trilha sonora do Hino Nacional foi capaz de derramar lágrimas de crocodilos de muitos ministros, militares e deputados biônicos. Alguns coçaram os dedos dentro de seus bolsos. Com Garrastazu Médici nada mudou, só piorou. Agora tinha o elemento ufanista misturado com repressão. Respeitar a bandeira nacional era a palavra de ordem. Ame-o ou deixe-o o Brasil. Na sua pátria não há escolha camarada! "Eu te amo meu Brasil, eu te amo", de Dom e Ravel era o hit estatal nas rádios AMs.

Pergunta o Boletim Hyponmenata (2015): Seria fortuito encontrarmos Rosane Collor entre os manifestantes? Que tal a presença de Carlinhos Metralha, o famigerado Capa Preta e capanga do delegado Fleury durante sua gestão no DOPS de São Paulo. Seria mera coincidência a presença de grupos fascistas, neonazista e skinheads nesse evento tão patriótico!

Entre marcha e manifestação há uma grande diferença. Marcha é coisa de militar. Remete a ordenamentos sociais, disciplinas e condutas. Também não há nada de jovial na manifestação. Há 
muita tolice, preconceito e oportunismo cabotino. O que se viu foi uma clamação pública por mais Estado, menos política e mais polícia. Camus em "O Homem Revoltado" (1951), dizia que o revoltado é antes de tudo alguém que se rebela. Se antes recebia chicotadas, agora enfrenta o chicote do senhor. Mas revolta ao som de micaretas e uniformidades de bandeiras é suspeito. Alegar crises e mais crises de todas às ordens é insano. É crise de representação? Econômica? Política? Institucional? Educacional? Revoltar-se e compartilhar selfies com policiais é a anti-revolta. "Nem todo valor acarreta revolta, mas todo movimento de revolta invoca tacitamente um valor. Trata-se de realmente de um valor?".

Tá ai o resultado de nossa direita que se diz democrática. Qualquer semelhança com fascismos não é mera coincidência. Disputas de partidos, creio que não. Mas o que vi mesmo é o policial de cada dia dentro de cada indivíduo, o policial de si e dos outros. Quando a polícia entra na alma da gente, a porrada é mais dolorida. O que o fascista mais deseja é controlar de dentro para fora e de fora para dentro.

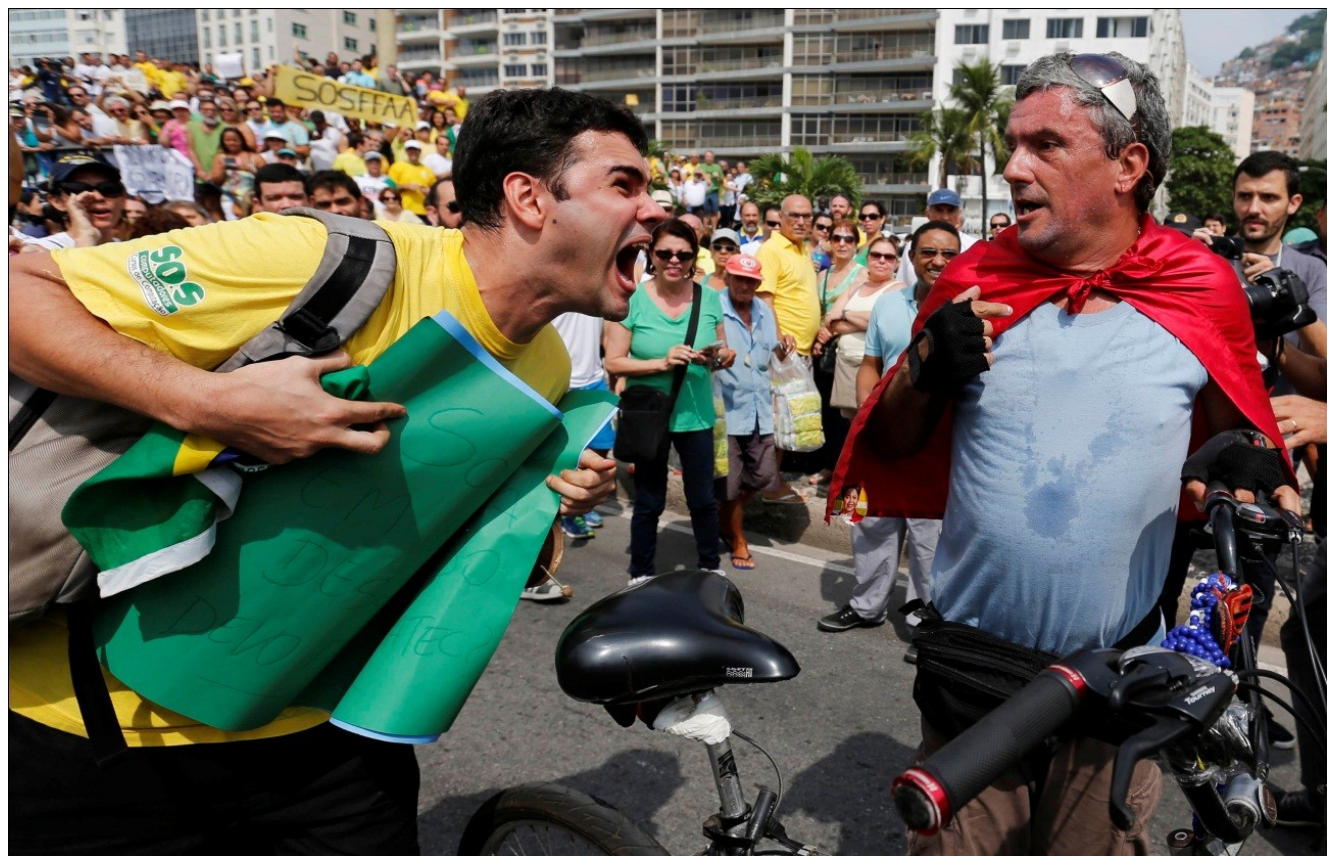

Foto disponível em http://ideiascadentes.blogspot.com.br/2015/03/um-novo-junho.html. Último acesso em 21/05/2015 


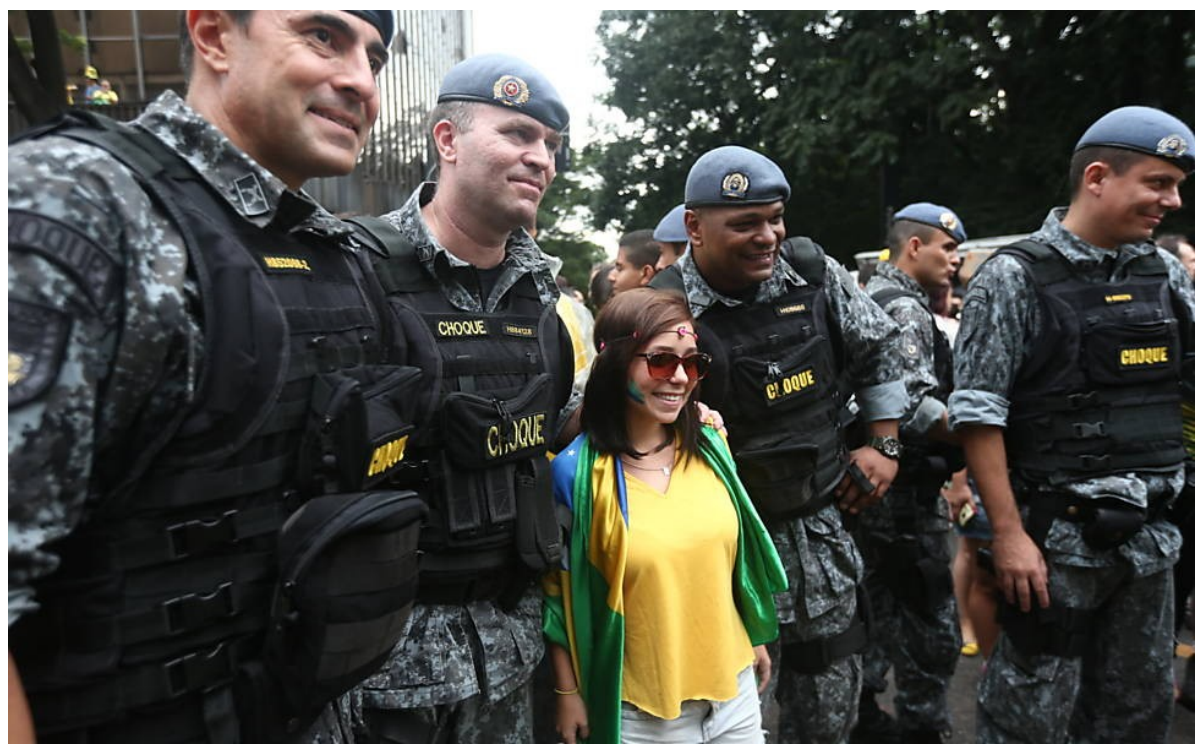

Foto disponível em http://www.pco.org.br/nacional/a-pm-que-nao-reprime/abpp,i.html. Último acesso em 21/05/2015 